\title{
The consequences of the loss of verb-second in English: information structure and syntax in interaction ${ }^{1}$
}

\author{
BETTELOU LOS \\ Radboud University Nijmegen \\ (Received 13 February 2008; revised 10 December 2008)
}

\begin{abstract}
English syntax used to have a version of the verb-second rule, by which the finite verb moves to second position in main clauses. This rule was lost in Middle English, and this article argues that its loss had serious consequences for the information structure of the clause. In the new, rigid subject-verb-object syntax, the function of preposed constituents changed, and the function of encoding 'old' or 'given' information in a pragmatically neutral way was increasingly reserved for subjects. Pressure from information structure to repair this situation subsequently led to the rise of new passive constructions in order to satisfy the need for more subjects; the change in the informational status of preposed constituents triggered the rise of clefts. If information structure can be compromised by syntactic change in this way, this suggests that it represents a separate linguistic level outside the syntax.
\end{abstract}

\section{Introduction}

Ever since the work done by the Neogrammarians in the nineteenth century, we know that sound changes may disrupt morphological paradigms, with morphological regularity often being restored by the process known as 'analogy'. An example is the Latin intervocalic $-s->-r$ - that disrupted the paradigm of the s-stem nouns: the $-s$ remained in nominative honos 'honour' because it was not intervocalic in that position, but changed to $-r$ - in the rest of the paradigm: honoris, honorem, etc. Analogy then intervened by 'regularizing' the nominative honos to honor (Hock 1986: 180). Similar disruption was caused by Verner's Law, where a sound change that was conditioned by syllable stress applied exclusively to some but not to other forms in the verbal paradigm (Verner 1875). Such changes exemplify the relative autonomy of the various linguistic levels: phonological change is 'blind' to the disruption it causes to other levels. Another example is Roberts \& Roussou's (2003) hypothesis that syntactic change (more especially grammaticalization) is driven by morphological loss. The situation could be summed up by Lightfoot's dictum: 'grammars practise therapy, not prophylaxis' (Lightfoot 1979: 123).

The present article will argue that changes in syntax may similarly disrupt information structure (IS). Its case study will be the loss of verb-second in English, which prompted 'therapy' in early Modern English in the form of new clefts and new passive structures - even to structures that are typologically very marked. The change

\footnotetext{
${ }^{1}$ I would like to thank Anthony Warner and two anonymous referees for their comments on earlier drafts of this article.
} 
in the syntax apparently ran its course in spite of the havoc caused at the IS level, which demonstrates that IS and syntax are just as autonomous as the phonology and morphology of the Neogrammarian examples above.

\subsection{Syntax and information structure}

Information structure is about placing pointers to hearers that allow them to keep track of referents, and to link pragmatically unrecoverable information (new information) to what is already known or presupposed. These pointers may be morphological (with special suffixes or particles, as in (1) below), or syntactic. Lambrecht (1994) notes, for instance, that all languages show some degree of competition, with marked topics and marked foci typically competing for the privileged first position.

Whether syntax drives information structure, or information structure drives syntax, is still unclear. There have been many recent attempts to integrate IS into syntax usually into syntactic models that already incorporate morphology. Rizzi (1997) incorporates IS notions like Topic and Focus into the syntax by positing functional constituents like TopicP and FocusP on the left edge of the clause, with minimal elaboration on how these concepts are defined. In such a perspective, TopicP and FocusP are morphological notions in some abstract sense, attracting relevant clause material in order to check a morphological feature. This model could work well for languages in which IS notions are marked by morphological markers, like Gungbe, in which Topics occur on the immediate left of a topic particle yà, and focused NPs on the immediate left of a focus particle $w \varepsilon$ (Aboh 2004, 2006):

(1) Ùn do do Àsíbá yà làn we é ní xว nà mí. 1-SG say that Asiba Top meat Foc 3-SG ní2 buy for 1-sG 'I said that, as for Asiba, she should buy me some MEAT.' (Aboh 2006: 24)

Syntactic change might then be due to the loss of topic and focus markers, leading to word order change, or reanalysis of the topic as subject.

When IS notions are associated with particular word orders or syntactic positions rather than morphemes, things get rather more challenging, especially if new types of focus constructions arise in an entirely different portion of the clause. Such causal relations are difficult to explain in a model which incorporates IS notions into the syntax. If IS is syntax, how could the information structure of a language be compromised by changes elsewhere in the syntax? How could a particular focus position become unavailable for checking in the first place? The conclusion must be that IS and syntax represent different linguistic levels, with any interaction between the two achieved by mapping rather than by subsuming one into the system of the other; see e.g. Neeleman \& van de Koot (2007).

To demonstrate that IS and syntax are separate modules that interact only in the sense that core IS 'rules' must be satisfied, and are mapped with available syntactic structures, 
I will take the loss of verb-second, and its consequences for the information structure of English, as my case study. I will argue in what follows that the information-structural function of the first constituent in English differed in fundamental ways before and after the loss of the verb-second rule. Before its loss, the first constituent was multifunctional in that it could encode marked and unmarked topics, as well as marked focus; after its loss, these functions were divided between the subject (unmarked topic) and the presubject constituent (marked topic, marked focus). The new function assigned to the subject put pressure on the syntax to provide more strategies to create subjects. We accordingly find that the number of passives goes up in late Middle English and early Modern English (Seoane 2006), and that they start to include passive constructions that are crosslinguistically rare, and were not attested earlier: prepositional passives of the type The doctor was sent for (see e.g. Denison 1985) and passive Exceptional Case-Marking (ECM) constructions with to-infinitives, as in John was said to be lying. Significantly, ECM constructions often are only acceptable in the passive, not in the active (cf. * Bill said John to be lying), which is unexpected in view of the fact that most theories regard actives as syntactically more basic than passives. Passive ECMs are in fact labelled 'information packaging constructions' by Birner \& Ward (2002: 1365ff.), who acknowledge their somewhat anomalous position in the syntax of Present-day English and provide an IS rationale for their existence.

Another innovation that was IS-driven is the cleft construction known as the stressedfocus cleft (Prince 1985), which has the form but not the function of a restrictive relative clause. Clefts in general represent yet another 'information packaging construction' and are discussed as such by Birner \& Ward (2002). The stressed-focus cleft has two subtypes, both of which represent eModE innovations, and we will demonstrate that the IS functions that they express were earlier encoded by constructions that require verb-second syntax.

Before we embark on a discussion of how these innovations helped to compensate for the loss of IS functions entailed by the loss of verb-second, we will first present some background to the phenomenon of verb-second in Old English. Although the data will initially be presented in a formal generative framework, it should be noted that the discussion itself is not theory-dependent; its main burden will be the changing functions of the first constituent of an English sentence.

\section{Verb-second in the history of English}

\subsection{Verb-second in Old English}

Languages like Dutch and German exhibit different word orders in main and subclauses: subclauses are verb-final, whereas main clauses have the finite verb in second position. With the advent of transformational generative theory, this phenomenon obviously called for an explanation in terms of a transformation - but which order should be taken as underlying, and which as derived? Koster (1975) argued persuasively that 
the underlying order should be assumed to be the Subject-Object-Verb order of the subclause. Main clause orders can then be derived by two movement rules: one that puts the finite verb into second position, and a second rule that topicalizes a constituent from the clause into first position. This constituent may be moved from any position in the clause, and may have any syntactic function.

Crosslinguistically, main and subclause asymmetries are a common phenomenon: main clauses are affected by various communicative requirements (information structure), the positioning of focus and of discourse-old or discourse-new material, and they therefore tend to develop special constructions not found in the subclause (see Bybee 2001); the first position of a main clause is a 'cognitively privileged position' for which marked topics and marked foci naturally compete (Lambrecht 1994: 31-2). Koster's assumption of underlying SOV for Modern Dutch fits the intuitive notion that Germanic was SOV at an earlier stage but developed verb-second in main clauses initially as a response to IS pressures; the motivation behind verb-second may have been at first stylistic, an optional rule to draw attention to the special IS status of the first constituent. The finite verb may possibly have functioned as a focus marker first, as still in Hungarian (Comrie 1989: 63), but must have become entrenched as a syntactic device to mark the modality of the clause (with interrogative or negative in first position) or to regulate the narrative flow (with a narrative adverb, like OE $p a$ 'then', or topic, in first position). These two categories can in fact be collapsed into one of 'clause typing'. 2

Using Koster's diagnostic tests, van Kemenade (1987) demonstrates that OE has a rule of verb-fronting similar to the one exhibited by Modern Dutch and German, but with an important difference. When the first constituent is a wh-word, the negator ne or a member of a restricted group of adverbs, most prominently $b a$ 'then', the finite verb (in bold in (2)) will immediately follow in second position, as it does in Modern Dutch or German, with the subject, whether nominal or pronominal (as he in (2)), in the third position:

(2) Pa gemette he ðær ænne pearfan nacodne then met he there a beggar naked 'Then he met a poor man, naked' <ÆLS (Martin) 61-62>3

However, when the first constituent is not a $w h$-word, the negator ne or an adverb like $p a$ 'then', but a topicalized nominal or prepositional object, or adjunct, like After bysum

2 The contrast between the $p a$ 'then' $-V-S$ sequence in main clauses and the $b a$ 'when' $-S-V$ sequence in subclauses suggests that $p a$, although originally a narrative adverb, has become entrenched in strategies of clause typing and discourse marking in OE (van Kemenade \& Los 2006).

3 The reference to an OE text enclosed in $<>$ follows the system of short titles as employed in Healey \& Venezky (1985 [1980]) (in turn based on the system of Mitchell, Ball \& Cameron 1975, 1979). It is identical to the TEI reference in the Toronto Corpus, which means that line numbers refer to the beginning of the sentence rather than the line in which the relevant structure occurs. 
wordum 'after these words' in (3), subject nominals are still in the third position, but pronouns are not: instead they precede the finite verb, which now appears to be in third place (in bold):

(3) Æfter pysum wordum he gewende to pam ærendracan

After these words he turned to the messenger

'After these words he turned to the messenger' $<$ ELS (Edmund) 83>

Van Kemenade (1987) argues that pronouns are clitics in OE and attach to V, which would explain why they show up to the left of the finite verb in (3); (3) would then also be an example of verb-second, with the verb still moving to the same position (identified as $\mathrm{C}$, the head of $\mathrm{CP}$, the highest projection of the clause) even though it appears to be in third place in surface structure. Pintzuk (1991) argues that the verb does not move as high as $\mathrm{C}$ in sentences like (3) but to I (the head of IP, the 'Inflection Phrase'). More recently, data like (2) and (3) have been interpreted as demonstrating the existence of a separate projection for clitic pronouns (van Kemenade 2000; Haeberli 2002), with distinct structural positions for pronoun subjects and full nominal subjects, and two positions for the fronted finite verb. This means that the finite verbs of (2) and (3) are in different positions after all, as argued by Pintzuk (1991): in C in (2) (see the tree structure in (4)), and in the head of a lower functional projection which Haeberli (2002) and Warner (2007) identify as AgrSP in (3) (see the tree structure in (5)). Note that AgrSP and TP now host information that used to be situated in IP in earlier versions of the theory (following the proposal of the Split IP in Pollock 1989).

(4)

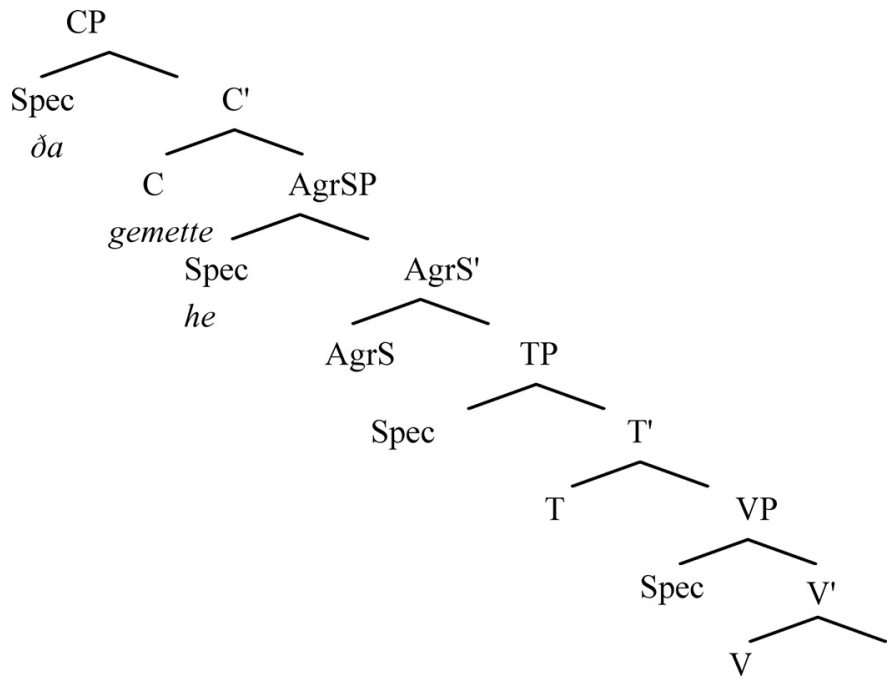


(5)

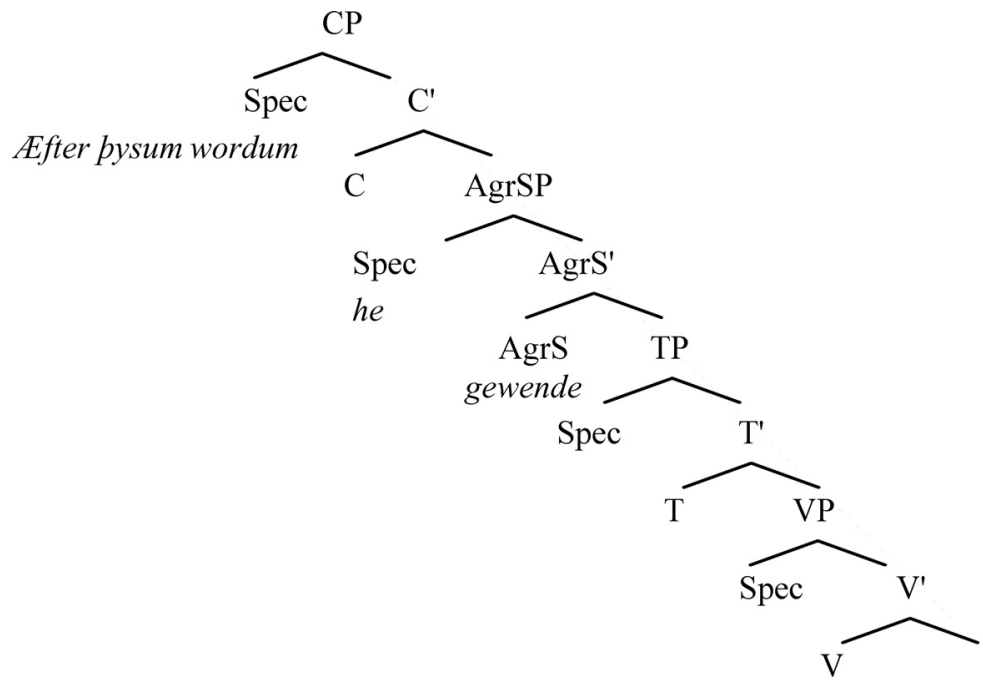

Full nominal subjects after first constituents other than 'operators', as in (6), appear to be positioned in a low position, SpecTP (see the structure in (7), following Warner 2007: 88). (An operator is a $w h$-word, the negator ne or an adverb like $p a$ 'then'.)

(6) And egeslice spæc Gregorius be ðam and sternly spoke Gregorius about that 'and Gregorius spoke sternly about that' $\quad(<$ WHom 10c, 48>; Warner 2007: 88)

(7)

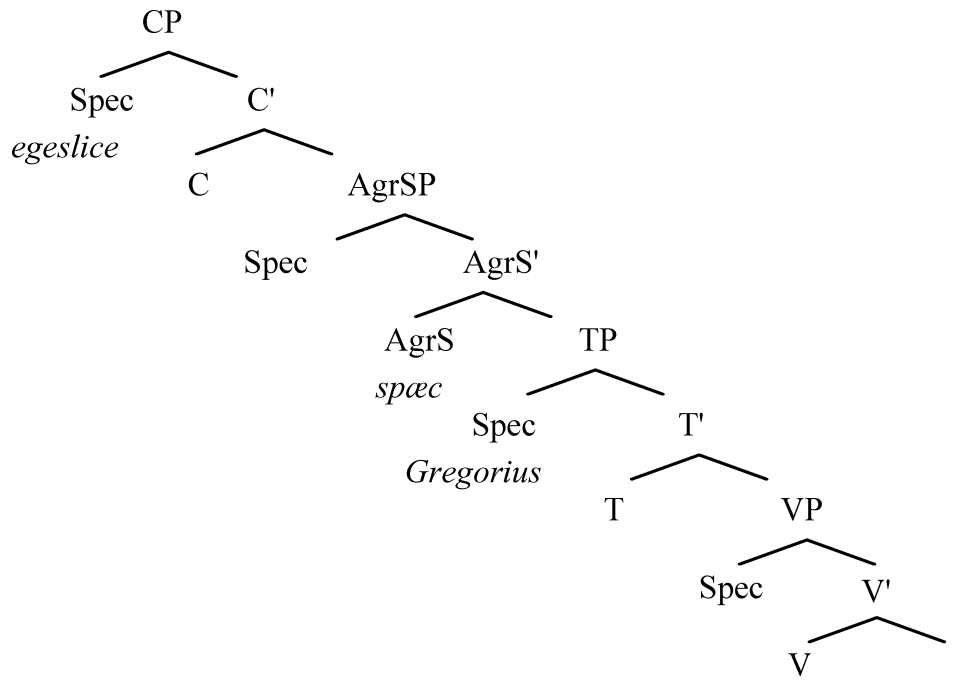

For full nominal subjects following operators, two positions suggest themselves: either SpecAgrSP, the same position as the pronominal subject in (4), or SpecTP, the same 
position as the full nominal subject after non-operator first constituents. Haeberli (2002) argues that full nominal subjects of both types are in the lower position, with the higher SpecAgrSP position occupied by a null expletive pronoun. This would make SpecAgrSP the position for all pronouns, both overt and null.

It has often been demonstrated that Old English is not consistently verb-second, even if we think of verb-second as shorthand for verb movement to any higher head (whether $\mathrm{C}$ or AgrS), regardless of whether the surface result is the second or third place; there are cases in which the verb fails to move at all in main clauses and remains in clausefinal position in the main clause (with a very low frequency; see e.g. Koopman 1995) or in the second or subsequent conjuncts of coordinated main clauses (with reasonable frequency; see e.g. Mitchell 1985: 710ff.). There are also cases in which more than one constituent precedes the finite verb (in cases other than those of (5) with pronominal subjects), with some considerable frequency, as has been noted by Breivik \& Swan (1994: 15) and Haeberli (2002). The interpretation of such cases is not easy. Unlike Breivik \& Swan, Haeberli manages to tease out cases like (5) as a consistent pattern, as well as possible cases of verb-final; the cases that are left could do with some further analysis. Some instances pattern like the modern West Germanic languages that similarly allow two constituents before the finite verb in special conditions: if the first item is a rhetorical metacomment like a propositional adverbial of the type certainly (cf. the cases with witodlice 'certainly' and soplice 'truly' in Breivik \& Swan's 1994 data), which should probably be analysed as being outside the clause proper (see Hasereyn et al. 1997: 1278 for Dutch). Such clauses, then, should still be analysed as verb-second. Dutch also allows two adverbial phrases before the finite verb under wellstudied conditions (Smits 2002; see also Auer 1996's definition of the pre-frontfield in German), with some frequency, and similar cases in $\mathrm{OE}$ and ME should still be analysed as verb-second. ${ }^{4}$

There is yet another possible position for the subject in $\mathrm{OE}$, the 'late subject' position:

(8) Fæder her is cumen an eunuchus of cinges hirede wilnað thinre spræce. father here is come a eunuch of the-King's household wants your speech 'Father, a eunuch from the King's household has arrived who wants to talk to you.' $<$ LS 7 (Euphr) 137>

The subject, an eunuchus of cinges hirede, follows not just the finite verb but the entire verbal string. Late subjects may occur in $\mathrm{OE}$ when the verb is passive or unaccusative and can therefore be analysed as objects in the underlying structure which have either failed to move to the subject position (SpecTP) or have done so but have then been

4 Typical Dutch examples (from Smits 2002: 168):

(i) Later, als ambassadeur bij de VN, onderhandelde hij met de Chinezen. 'Later, as a UN ambassador, he negotiated with the Chinese.'

(ii) Morgen aan de Zwarte Zee kun je lekker beginnen te luieren.

'Tomorrow on the Black Sea beach you can start to relax.' 
postposed to the end of the clause. This construction allows the subjects that are informationally new to appear in the end-focus position (presentational focus). Warner (2007) notes that a sentence like (9) is derivationally ambiguous:

(9) Of pese seuene heuedes comen alle manere of synnes

from these seven heads come all manner of sins

'From these seven heads spring all manner of sins' (Vices and Vertues 11.8)

One possible derivation is as in (7) above, with the verb in AgrS and the nominal subject in SpecTP, but because the verb is the unaccusative comen it is also possible that the subject in (9), alle manere of synnes, is a late subject; see Warner (2007) for an extensive discussion. The existence of late subjects further complicates attempts to chart the decline of verb-second in the fifteenth century.

To summarize: XP - Vfinite - Subject clauses in OE and ME cannot all be taken as straightforward instances of verb-second, just as XP - XP - Vfinite clauses cannot all be taken as instances in which the verb has failed to move. Four patterns need to be distinguished when attempting to chart the decline of verb-second:

(i) Negation/Wh-word/pa 'then' $-\mathrm{V}_{\text {finite }}-$ Subject, as in (2) and (4). This pattern survives in PE as subject-auxiliary inversion and has been analysed as 'residual verb-second' (Haerberli 2002: 247); see e.g. (10) below.

(ii) $\mathrm{XP}-\mathrm{V}_{\text {finite }}$ - nominal subject, as in (6)-(7). This pattern does not survive in PE.

(iii) $\mathrm{XP}$ - pronominal subject $-\mathrm{V}_{\text {finite }}$, as in (3) and (5). Although this order appears to survive in $\mathrm{PE}$, the choice of $\mathrm{XP}$ is much restricted in $\mathrm{PE}$, and its function much more circumscribed, as we will see below. The pronominal subject is much lower in PE (it is in the same position as nominal subjects, i.e. the low SpecTP position of the subject in (7)), and the (lexical) verb is much lower too, arguably remaining in its base position; the loss of verb movement for lexical verbs in lME is reflected in the rise of $d o$-support in eModE, and the fact that the lexical verb follows rather than precedes adverbs: John never walks to work.

(iv) $\mathrm{XP}-\mathrm{V}_{\text {finite }}-\left(\mathrm{V}_{\text {non-finite }}\right)-$ late subject, as in (8). This pattern survives in $\mathrm{PE}$ as 'inversion'; see e.g. (11)-(12).

\subsection{The special function of the first constituent in a verb-second system}

Haeberli's finding that verb-second did not apply as strictly in OE as it does in the modern West Germanic languages might leave us with the impression that the loss of verb-second was merely a quantitative rather than a qualitative break, with subject-verb inversion gradually ceasing to be a 'clear majority pattern' (Haeberli 2002: 252). If we think of verb-second in terms of a system that provides a slot in the initial position of the clause for discourse linking independent of the subject, the loss of verb-second entails the loss of this special position and is more than a falling off of frequencies.

The function of the first constituent in the modern West Germanic languages is revealed in a contrastive study by Bohnacker \& Rosén (2007), who report on the problems encountered by Swedish students in the L2 acquisition of German. As both Swedish and German are verb-second languages, it is not the second position of the finite verb that presents problems; it is the first constituent. The Swedish learners start 
Table 1. A comparison of rates of subjects versus other first constituents in Modern German, Modern Swedish and $O E$

\begin{tabular}{lllc}
\hline \hline Corpus studies & $\begin{array}{l}\text { Subject } \\
\text { first }\end{array}$ & $\begin{array}{l}\text { Adverbial } \\
\text { first }\end{array}$ & Other \\
\hline German spoken corpus (Engel 1974: 212-15) & $51 \%$ & $35 \%$ & $14 \%$ \\
German newspaper corpus (Fabricius-Hansen \& & $54 \%$ & $35.8 \%$ & $9.2 \%$ \\
$\quad$ Solfjeld 1994: 101-2) & & & \\
OE: Joseph in Egypt (<Gen (Ker)>) & $52 \%$ & $43 \%$ & $5 \%$ \\
Swedish (Bohnacker \& Rosén 2007: 36) & $73 \%$ & $23 \%$ & $4 \%$ \\
\hline \hline
\end{tabular}

too many of their German sentences with subjects, including expletives, 'organizing and structuring information in a way that native German readers find odd and unidiomatic' (ibid. 31). First constituent frequencies gauged from various studies confirm that the Swedish rate of subjects as the first constituent is higher: 73 per cent compared to 5154 per cent in Modern German (table 1). Swedish apparently has a stronger tendency than German to have items of low informational value in first position. The first constituent in German is far more versatile and can easily accommodate completely new information, and this accounted for some of the native-speaker judgements. The most significant difference, however, turned out to be use of the first position primarily for discourse reference and text cohesion, with a large proportion (some 30 per cent) ${ }^{5}$ of the nonsubject-first constituents (the adverbials in first position) consisting of one of the so-called Pronominaladverbien 'pronominal adverbs': adverbs formed by an anaphor like $d a$ 'there' and a preposition: dazu 'there-to', darauf 'there-on', daran 'thereon', damit 'there-with', davon 'there-of', darum 'there-about', dafür 'there-for', danach 'there-after'(ibid. 49). The preference for deictics is also reflected by high frequency of the temporal adverb dann 'then' in first position. German speakers also front objects at a higher rate, and the object pronouns allow very specific reference to earlier entities in the discourse because they are gendered (den, die, das). Bohnacker \& Rosén conclude that the morphological complexity of the German pronominal system, including the pronominal adverbs, combines to establish textual cohesion as the primary function of the first constituent - in marked contrast with Swedish, where (at least in the standard variety) the absence of gendered nouns means that specific reference is more difficult to achieve: there is only det 'that'.

A preliminary study of an OE text showed results very similar to Modern German. The text selected was the Joseph in Egypt episode from Genesis (Crawford 1922: 170203): it is predominantly narrative, and its style is straightforward and unadorned, and so, it was hoped, comparable to the German newspaper corpus and spoken corpus in table 1. The electronic version of this text fragment in the Toronto Corpus contains 255

\footnotetext{
5 Bohnacker \& Rosén's (2007) German controls used pronominal adverbs as first constituent at a rate of 11 per cent overall (of all first constituents), which works out as some 30 per cent of all adverbial first constituents.
} 
Table 2. The first constituent in the narrative of Joseph in Egypt (Genesis)

\begin{tabular}{|c|c|c|c|c|c|}
\hline \multicolumn{5}{|l|}{ First constituent } & \multirow{2}{*}{$\begin{array}{l}\text { Total } \\
232(52 \%)\end{array}$} \\
\hline Subject & Nominal: 78 & Pronominal: 134 & Demonstrative: 20 & & \\
\hline Object & Nominal: 9 & Pronominal: 7 & Demonstrative: 3 & & $19(4 \%)$ \\
\hline $\begin{array}{l}\text { Adverbial phrase } \\
\text { or clause }\end{array}$ & $\begin{array}{l}\text { Conditional } \\
\text { clause: } 7\end{array}$ & pa/ponne: 135 & $\begin{array}{l}\text { Containing } \\
\text { demonstrative: } 32\end{array}$ & Other: 18 & $192(43 \%)$ \\
\hline Other & Predicate: 3 & Left Dislocation: 1 & & & $4(1 \%)$ \\
\hline Total & & & & & 447 \\
\hline
\end{tabular}

citations, which broke down into 644 main clauses. ${ }^{6}$ After discounting clauses with ellipted subjects, e.g. those preceded by and conjoined to other main clauses with which they shared their subject, and imperatives, subjunctive wishes, wh- or yes/no questions, the remaining 447 declarative clauses yielded rates of subject-first and adverbial-first very similar to the Modern German corpora (table 1). The first constituent functions could be broken down as shown in table 2 .

Table 2 demonstrates the prominent function of the first constituent as a position to establish textual cohesion, particularly in the case of the nonsubjects: the adverbials, where deixis is prominent - ba/ponne 'then' as temporal adverbs, poer/her 'there/here' as spatial adverbs - and the articulate system of demonstratives as the OE equivalent of the German pronominal adverbs - puruh poet 'through that (particular thing)', be pare 'by that (person)', forðam 'for that', after pam 'after that', aefter pisum 'after this'. Many other adverbial links contain referring demonstratives: on poes handa 'in whose hands', etc. The results of this preliminary study, then, seem to point to the first position as having a function very similar to that outlined by Bohnacker \& Rosén for German. Translating such nonsubject textual links, particularly pronominal adverbs, in first position into $\mathrm{PE}$ reveals that the presubject position in an $\mathrm{XP}-\mathrm{S}-\mathrm{V}-\mathrm{O}$ structure cannot be equated with the first constituent position in the modern West Germanic languages, as we will see below. The contrast with Swedish in this respect demonstrates that verb movement by itself is not a sufficient condition to ensure the functionality of the first position as a discourse link; the system of deictic referencing needs to be sufficiently articulated. ${ }^{7}$

${ }^{6}$ There is the usual grey area of coordination shading into subordination in OE texts, particularly in the case of some relative clauses of the se-type, and clauses beginning with conjunctions like forpam (pe), but these doubtful cases affect the overall figure only minimally.

${ }^{7}$ In the light of Bohnacker \& Rosén's (2007) findings it is tempting to see the loss of gender as an important trigger, with the situation of Standard Swedish, including its high rates of subject-first clauses, representing a stage in the ultimate loss of verb-movement; this is a matter for future research. The decline of the pronominal adverbs - containing an explicitly deictic pronominal element - in English has been charted by Lenker, who 


\subsection{The decline of verb-second}

Verb-second starts to decline in the Middle English period, for reasons that are as yet not fully understood. It has been claimed that the presence of inflections on a verb is an important cue in language acquisition that the language in question has verb movement (Roberts 1993; Roberts \& Roussou 2003) and that the loss of verb-second was triggered by the loss of verbal morphology. Haeberli (2002) argues that the higher SpecAgrSP position, the position reserved for pronouns, was occupied by an empty expletive pronoun when the overt subject was a full nominal; the decline of verb-second would then be due to the loss of empty expletive subjects in general. Lightfoot (1999) argues that certain cues need to be robustly present in the language learner's data to trigger the development of a verb-second grammar, and that these cues fell below a certain threshold due to the dialect contact situation of northern and southern dialects which ultimately derives from the contact situation with the Old Norse-speaking Viking settlers in the Danelaw area. This contact situation of the ninth and tenth centuries has also been argued to be at the root of the wholesale loss of nominal and verbal inflections in $\mathrm{ME}$, although the evidence about their impact on the English language is indirect: there are no texts from the relevant area and from the relevant period. The first extant texts date from well into the ME period, and filling in such a data gap calls for some well-informed guesswork (e.g. Townend 2002) and ingenious use of the material that we do have: northern-Old English glosses of a Latin text. Kroch, Taylor \& Ringe (2000) argue on the basis of such glosses that the contact situation with Old Norse may well have affected the verb-second rule more directly, at least in the northern dialects, as Old Norse exhibited a verb-second rule that was different from the OE rule in a number of crucial respects. This may have led to the simplified version of the rule that is evident from these northern glosses.

Smith, in his account of the origins of the Great Vowel Shift in late ME/eModE, emphasizes the importance of the demographic situation in fifteenth-century London as a hotbed for language change: the depopulation after the Black Death of 1349-50, the resulting changes in social structure and population mobility, and the rise of the wool trade, led to massive immigration into London from the north and the midlands. There were sociolinguistic changes as well: from the end of the fourteenth century onwards, French lost its status as language of the nobility (a legacy of the Norman Conquest), which meant that there was now room for an English variety to acquire social prestige and become a social 'distancer', the language aspired to by social climbers; the changing social structure now made it possible to fulfil such ambitions. People who change their speech in adulthood for reasons of prestige lack the languagelearning capacities of the child and tend to acquire their new 'lect' imperfectly, often overshooting their mark (Smith 1996). If the northern variety did indeed have a slightly different version of the verb-second rule, the contact situation in London may well

has investigated clausal connectors of cause and result and has found a 'complete restructuring' of the system of clausal connection in eME (Lenker 2007: 215). 
have precipitated the demise of the rule. Howell (2006) stresses the importance for the speakers in such a situation of dialect contact to be understood, and argues that the variety that resolves itself as common ground, or 'standard', for such speakers will tend to be a compromise that retains features that are common to the contact 'lects' and rejects features that are not, especially features that are perceived as typical of a particular lect. Similar observations have been made in the literature on pidgins and creoles, which suggests that the new norm does not simply settle on the lowest common denominator but represents the cumulative result of different speakers' perceptions of what they have in common and what they do not - a marked word order in one lect may be perceived as similar to an unmarked order in another lect (Thomason 2001: 181). SOV languages in contact have been known to give rise to SVO creoles for this reason (Kouwenberg 1992). As a result of all of these factors, language-internal as well as language-external, verb-second declined and the word order of Present-day English, rigidly SVO, emerged.

The decline of verb-second ('inversion') presents a diffuse, confusing picture. Jacobsson (1951) and Schmidt (1980) report a steep decline from the late fourteenth century onwards, with a short-lived revival in the sixteenth century. Nevalainen (1997), on the other hand, reports a steady decline from 37 per cent in the fifteenth century to well below 10 per cent at the close of the seventeenth century. Bækken's (1998) extensive corpus research spans the relevant period (1480-1730), but in spite of presenting over two hundred tables of figures, she cannot report any definite trend apart from the fact that verb-second becomes really uncommon only after 1630. All these studies report wildly varying rates of verb-second, within individual periods, individual text types and even individual writers.

Part of the problem, as noted in Fischer et al. (2000), van der Wurff (2001) and Warner (2007), is that some of these studies ignore the theorizing that has been developed about the phenomenon of verb-second in Germanic, which might explain why no systematic patterns emerge. We saw at the end of the previous section that XP $-\mathrm{V}_{\text {finite }}-$ Subject clauses cannot all be taken as straightforward instances of verb-second. Pronominal and nominal subjects need to be kept apart, as well as instances of late subjects. By the same token, the nature of the first constituent is important, too; some studies keep interrogatives or negative phrases apart but are unaware of the special behaviour of discourse adverbs like OE $p a$ 'then', or eModE then or now, etc., and do not distinguish between these and topicalized constituents - thus missing the important point that the verb fronts to a lower position with topics. Similarly, movement of the lexical verb must be distinguished from movement of auxiliaries; the latter is a purely syntactic phenomenon in Present-day English (PE), triggered by a wh-or negative element in first position, including adverbs such as only 'not more than' or rarely 'not often' as in (10a) or quantified NPs as in $(10 b-c)$ :

(10) (a) Rarely did I hear such overtones of gratitude as went into the utterance of this compound noun. (Green 1980, ex. (32e), cited in Birner \& Ward 1998: 157)

(b) Many a mile did I walk before I saw a light.

(c) So little time did we have that we had to cut corners.

(Huddleston \& Pullum 2002: 96) 
Then there are instances like PE (11)-(12), which appear to be reflexes of the OE/eME late subject construction we saw exemplified above in (8)-(9); the relevant verbs are given in bold.

(11) [Performer] offers to cause the card to penetrate the deck and the handkerchief and come out on the table. But when he lifts the bundle, nothing has happened. He tries again and this time, on top of the folded hanky is seen the imprint of the selected card! (Magic Inc. Trick Catalogue no. 25, p. 71; from Birner \& Ward 1998: 157)

(12) To the left of the altar one of the big wall panels with rounded tops opens, it is a secret door like in a horror movie, and out of it steps Archie Campbell in a black Cassock and white surplice and stole.

(Updike 1981: 242, from Birner \& Ward 1998: 158)

Although the construction illustrated by (11)-(12) is usually referred to as 'inversion', it appears to be the reflex of the OE late subject construction we saw in (8)-(9) above. Unlike the subject-auxiliary 'inversion' of (10), we have an entire verbal string (a passive) or a non-auxiliary (an unaccusative) preceding the subject, just as in (8)-(9); see e.g. Quirk et al. (1985), Birner \& Ward (1998).

Any 'late subjects' like (11) encountered in IME and eModE, the crucial period for the loss of verb-second, should be kept separate and not counted as a possible instance of verb-second; they do not involve verb-movement. Cases with a single lexical, and unaccusative, verb like (12) are even more difficult to deal with because they are derivationally ambiguous (Warner 2007; see also Haeberli's (2002: 253-5) discussion of what he labels Type I and Type II inversion in Middle English). They might be instances of late subjects, like (11), but they could also be instances of verb-second if they are the output of a grammar which retains verb-second and which does not yet recognize auxiliaries as a separate category. The crucial period here is the sixteenth century, as is evident from the rise of $d o$-support in this period (Ellegård 1953). ${ }^{8}$ Once auxiliaries emerge as a category separate from lexical verbs, movement to higher positions becomes their exclusive prerogative (as in (10) above); from that point on, lexical verbs stay put in the VP. After the loss of verb-second, instances like (12) can only be analysed as late subjects and not as evidence of verb-movement and reflexes of verb-second. If investigators do not realize this, they might count them as instances of verb-second and conclude that verb-second was alive and kicking when it was in fact in decline. It is the derivational ambiguity of data like (12) that makes charting the decline of verb-second in the $1 \mathrm{ME}$-eModE period particularly hard; one might conclude that sixteenth-century instances that look like (12) are better left out of the investigation altogether.

Warner (2007) presents a study that does take all these insights into account, and a more systematic picture emerges: his figures show that the late subject construction is stable in the fifteenth century, whereas other types of inversion decline (Warner 2007: 103). These are the types Warner labels 'inversion in final contexts', where the verb

\footnotetext{
${ }^{8}$ For an overview of the literature on the rise of auxiliary as a separate category, see Denison (1993). Ellegård's data are statistically interpreted and evaluated in Kroch et al. (1982), Kroch (1989) and Warner (2004). The latter also adds new data.
} 
when not inverted would have been clause-final, as in (13), and 'inversion in internal contexts', where the finite verb (in uninverted cases) or the subject (in inverted cases) is followed by a complement, as in (14). The relevant verbs are given in bold:

(13) Alswa, clennes of mouth, kepes thre thynges: Ane es pat pou umthynk pe also, cleanness of mouth preserve three things one is that you consider you before, or pou speke.

before ere you speak

'Also three things preserve purity of mouth. One is that you reflect before you speak.'

(Rolle, The Form of Living, 25; from Warner 2007: 98)

(14) \& pus gat kyng acab the vinezard. and thus got King Ahab the vineyard 'And thus King Ahab obtained the vineyard.'

(Lavenham 9.37; from Warner 2007: 99)

Warner concludes that the subject in these types is probably not 'late' but in SpecTP, the normal subject position of PE, which means that the decline of verb-second translates in these instances as a failure of the verb to raise further than $\mathrm{T}$ - although the position of nominal subjects is in doubt in this period, as the loss of distinctive positions for pronoun and nominal positions in OE may well have led to nominal subjects being positioned in the high, erstwhile 'pronominal', position, SpecAgrSP. Finally, there is evidence from PE that inversion with verbs like speak, say (quotative inversion) or be (presentational inversion) needs to be considered separately, too: although they may derive from the verb-second construction, they appear to have acquired discourse characteristics of their own that set them apart from instances like (11)-(12) (Birner \& Ward 1998: 156-7); their inversion pattern was already distinct in IME (Warner 2007: 99-100). If quotative and presentational inversion instances are discarded, the data strongly suggest that verb-second was all but defunct by 1500 .

Warner concludes that inversion should not be studied as a single phenomenon, as it involves constructions that are formally different, and he recommends that further research should 'seek to integrate discourse properties into the analysis' (2007: 107). The role of information structure becomes even more important if we consider how the loss of verb-second restricted the language user's options for positioning given and new information. The eModE period seems to be a crucial stage. We will look at this aspect in the next section.

3 The loss of verb-second and its consequence for information structure

\subsection{The position of the verb}

After the loss of verb-second, subjects were apparently restricted to a low position; SpecTP for the canonical order, and a lower, possibly VP-internal, position if we regard Birner \& Ward's 'argument-reversing constructions' of (11)-(12) as the successor of the 'late subjects' of $\mathrm{OE}$ and ME. Further rigidification took place when auxiliaries 
emerged as a separate category in the sixteenth century, and lexical verbs could no longer move to AgrS or C but stayed put in the $\mathrm{VP}$ - as is evident from the rise of $d o$ support (Ellegård 1953), where a form of do moves from I to C instead of the lexical V, and from the position of adverbs. The resulting canonical order of $\mathrm{S}-\mathrm{V}$ seems to have compromised the ways that were available to the language user to structure information. A similar situation may have obtained in earlier French; Lambrecht (1994) points out that the various types of clefts in French are a response to the demands of information structure in a rigid syntax. In the modern West Germanic verb-second languages, the first constituent provides a separate position for discourse linking; in PE, unmarked discourse linking is a function of the subject rather than the position preceding the subject. Although much more work still remains to be done in this area, we will present some preliminary pointers on these functions. Translation studies (OE/IME/PE and Dutch/PE) show that the loss of verb-second entailed a change in the way in which unmarked and marked discourse links were encoded.

\subsection{Preposed objects}

Speakers tailor their utterances to what they perceive to be the information state of their hearers. Utterances can typically be divided up into a part that is already familiar to the hearer and a part that is new; the most informative element in the clause is also given phonological prominence (stress). The new information, the focus of the message, is best defined as the value of a variable $x$ in an open proposition; a sentence like (15a), from Birner \& Ward (2002: 1370), for instance, can be a possible response to three different questions $(15 \mathrm{~b}-\mathrm{d})$, each one corresponding to a different open proposition:

(15) (a) She bought a bag of rice.

(b) What did Mary buy a bag of? $\rightarrow$ Mary bought a bag of $x$.

(c) What did Mary buy? $\rightarrow$ Mary bought $x$.

(d) What did Mary do? $\rightarrow$ She did $x$.

Note that it is quite possible for $x$ to be an entity mentioned prior in the discourse ('discourse-old') but new in the sense of how it is related to the information of the open proposition, i.e. as expressing the value of $x$; see e.g. Prince (1981), Lambrecht (1994), Birner \& Ward (2002: 1370ff.) for a discussion of these and other facts.

The canonical SVO order of PE has been labelled the 'pragmatically neutral' order. In typical cases, the subject will encode old, and the complement new information, but special intonation may put new information in subject position (e.g. Lambrecht 1994: 29ff.). This means that SVO order in English is underdetermined with respect to the discourse properties of its constituents, in a way that preposed constituents as in (16) and (17) are not:

(16) G: Do you watch football?

E. Yeah. Baseball I like a lot better. (Birner \& Ward 1998: 38)

As Birner \& Ward point out, the topic here should not be construed as 'baseball' but as the entire category of 'sports', and this activation of the entire set explains why 
the effect is 'contrastive'. Similarly, in (17), the preposing of material in front of the subject comes with a predetermined interpretation:

(17) Did you buy a whole new wardrobe for school? No, I have lots of clothes. Most of my stuff my mom gets _ at Alexander's. (Birner \& Ward 2002: 1373)

They point out that the preposing here marks the entire open proposition My mom gets my stuff at $x$ as discourse-old information: the fact that the speaker is still at school makes it likely that their clothes are bought by their mother.

Corpus studies report a decline in the relative frequency of object preposing that starts in ME (e.g. Speyer 2005), ${ }^{9}$ and show that its informational function becomes more circumscribed; preposed objects are more often old information (Pérez-Guerra 2005: 357ff.). This observation is further corroborated by instances like (18) from earlier English, and their later translations:

(18) god weorc heo worhte on me good work she worked in me 'she performed a good work in me' $\quad<$ MT(WSA) 26.10>

Later (lME) translations of the same passage have a cleft, showing that preposed objects were not restricted to discourse-old material before the loss of verb-second (from Ball 1991:157):

(19) Ful guod weork it was and is: pat heo wurchez in me 'A full good work it was and is that she works in me' 1280-90 SLeg. (L) 66 (Magdalena)105

\subsection{Preposed adverbials}

Although PE preposed objects seem to have attracted more attention than other preposed material, there are signs that PE preposed adverbials, too, have a different informational status than clause-initial adverbials in the earlier verb-second grammar. Although an investigation into the information-structural properties of earlier texts necessarily has to remain coarse-grained, general patterns of use do emerge. Corpus studies confirm a decline in the relative frequency of clause-initial adverbials (Breivik \& Swan 1994). Unlike preposed objects, they show a decline in referentiality in that they tend to encode new information more often in PE than in eModE or $1 \mathrm{ME}$ (Pérez-Guerra 2005: 357ff.). The exact nature of the change in informational status still needs to be investigated, but some pointers can be gleaned from contrastive Dutch-English translation studies. Translating verb-second Dutch into the canonical (XP) $-\mathrm{S}-\mathrm{V}$ structure of PE throws up immediate problems that have to do with information structure rather than syntax. Consider (20) from Hannay \& Keizer (1993);

\footnotetext{
9 Speyer (2005) argues that the increased unacceptability of object preposing (in that it is now only allowed under very special conditions, as in (17)) is itself a consequence of the loss of verb-second: without the presence of an intervening verb, the sequence of object and subject leads to a prosodic clash.
} 
the translation given is the one they recommend:

(20) En daarmee was de tragedie van Bergkamp compleet and with.that was the tragedy of Bergkamp complete 'and that made Bergkamp's tragedy complete'

Note that (20) could have been translated more literally: and with that, Bergkamp's tragedy was complete is syntactically possible ('grammatical'), but this would not be faithful to the original, as the presubject adverbial is more prominent in the translation than it is in the original text; in Functional Grammar terms, it is an 'unmarked theme' in Dutch, but a 'marked theme' in English. English clauses only start with nonsubjects when they are informationally marked, i.e. when they represent 'marked themes'. To convey old information with the same lack of prominence, i.e. as an unmarked theme, English requires a subject (e.g. Downing \& Locke 1995 following Halliday 1994 [1985]). A similar instance is (21), again from Hannay \& Keizer (1993):

(21) Hier heeft Andy Cole zijn eerste hattrick gescoord.

here has Andy Cole his first hat-trick scored

'Here, Andy Cole scored his first hat-trick.'

'This is where Andy Cole scored his first hat-trick.'

Although the more literal translation Here, Andy Cole scored his first hat-trick is syntactically possible, Dutch learners are warned against such a direct translation of their verb-second-Topicalized adverbials, especially with adverbials of place; PE employs the preverbal adverbial position to express contrast, as in (22), from university grammar course material:

(22) Outdoors, it was very cold. Indoors, it was stiflingly hot.

A recurrent theme in translation handbooks is the advice to convert Dutch nonsubject themes into English subject themes, as is achieved in (21) by resorting to the $t h / w h$ clause (This is where), a pseudo-cleft in which the deictic NP subject replaces the preposed deictic pronominal adverbial (note that daarmee in (20) and hier in (21) are the same type of pronominal adverbs that feature prominently in OE and Modern German, as discussed above in section 2.2). Although this is a popular strategy to deal with first-position adverbials in verb-second source languages, especially with adverbials of place because they seem particularly prone to carry contrastive prominence in the preposed position in PE, it needs to be employed sparingly, as high frequencies of th/wh-clauses may themselves make the translation unidiomatic; PE does not seem to go in for the high frequency of overt linking of one sentence to the next that appears to be typical of the other modern West Germanic languages (see e.g. the contrastive PE/German study in Stutterheim \& Carroll 2005). Overall, presubject adverbials of place and time have an important function in textual organization in English (see e.g. Virtanen 1992), but not in discourse-linking.

Manner adverbials can be similarly problematic, and may require an InformativePresupposition it-cleft. The Informative-Presupposition it-cleft marks a proposition as fact rather than as salient shared knowledge, which is where it differs from a 
stressed-focus cleft (Prince 1978). Both types of clefts are IME innovations; Jespersen (1937: 86) notes the link between the development of rigid $\mathrm{SVO}^{10}$ and the rise of clefting, and he is echoed by Traugott (1972). The first clear examples of these types of cleft are in the fifteenth century (see particularly Ball 1994). Although the it-cleft builds on existing constructions like the relative clause, it differs pragmatically but also syntactically from these models. Cleft relatives like $(23 a-b)$ may mimic ordinary relatives in form, but a closer look reveals that such relative clauses do not modify the $\mathrm{N}$ that appears as their head in the usual way, (23a), and may even lack an N-head to modify, (23b); examples from Huddleston \& Pullum (2002: 1046).

(23) (a) It wasn't for me that he made the sacrifice.

(b) It's to avoid such a conflict of interests that I am resigning.

It is only in eModE that we get the first clefts with clausal foci (as in (23b)).

Dutch/English translation contrasts may go some way to explaining the need for such clefts in English after the loss of verb-second. In example (24) it is the second translation, with the cleft, that is the recommended one, not the more literal translation with the adverbial in presubject position:

(24) Met genoegen kunnen we $u$ meedelen dat uw aanvraag gehonoreerd is. with pleasure can we you inform that your application awarded is 'With great pleasure, we can inform you that your application has been successful.' 'It is with great pleasure that we can inform you that your application has been successful.'

A possible explanation for the clefted translation of (24) is that the presubject adverbial position in $\mathrm{PE}$ would convey greater informational prominence to the adverbial than its status in the original warrants; the function of the Informative-Presupposition itcleft, then, would be to place with great pleasure in end-focus position to make it less marked, which may sound somewhat of a paradox because clefts are marked structures themselves in the sense that they are not informationally neutral; but nothing else appears to explain the awkwardness of the more literal translation.

\subsection{The loss of Contrastive Left Dislocation}

The previous section mentioned the $t h / w h$-clause as a translation strategy to avoid positioning an adverbial of place in a prominent position. There is a second verb-second construction that can be translated by such $t h / w h$-clauses, and that is Contrastive Left Dislocation.

Ball's excellent study of the rise of the it-cleft in English compares the clefts found in Watts' PE translation of Boethius' De Consolatione Philosophiae with earlier translations of the same passages, just to see what structures English employed at

10 '[T]his construction may be considered one of the means by which the disadvantages of having a comparatively rigid grammatical word-order (SVO) can be obviated' (Jespersen 1937: 86); note that the idea that the rigidification is due to the loss of verb-second is my own claim, not Jespersen's. 
an earlier stage, before the existence of the new clefts, especially clefts with a clausal focus, which do not emerge until the seventeenth century (Ball 1991: 481). The earlier translations show that $\mathrm{OE}$ resorted to correlative constructions and preposing, and ME to a variant of the correlative that is perhaps better analysed as Left Dislocation and preposing; these two constructions can actually be argued to be one and the same construction in a verb-second language, as we will see below. The cleft of the PE translation in (25) shows up as a dislocation in the earlier translation (26), from Chaucer:

(25) If Nature gives them their beauty, how does it involve you? They would still have been pleasing by themselves, even if separated from your possessions. It isn't because they are part of your wealth that they are precious, but because you thought them precious that you wanted to add them to the sum of your riches.

(Watts 1969: tr. Bo 2. pr5.67; Ball 1991: 482)

(26) Forwhy fair ne precyous were thei nat for that thei comen among thi rychesses; but for they semeden fair and precyous, therfore thou haddest levere rekne hem among thi rychesses.

(Chaucer, tr. Bo 2.pr5.108; Ball 1991: 482)

Ball (1991: 484-5) explores the various PE options and concludes that it is only the cleft (as in (25)) that will do here; part of the problem is the anaphoric reference between deictic element and the preposed constituent it refers back to, witness the unacceptability of But because they are fair and precious, therefore $e_{i}$ you wanted to reckon them among your riches. An anaphoric PP, as in But because they are fair and precious, for that reason you wanted to reckon them among your riches, is marginally better, but lacks the specificational reading of the original. Specification can be restored by adding the focusing modifier precisely, which triggers inversion: precisely for that reason did you want to reckon them among your riches, but this is a marked, archaic order. Another option, just as marginal, is a pseudo-cleft with a deictic NP subject, as in But because they are fair and precious, that is why you wanted to reckon them among your riches - in other words, the $t h / w h$-clause that is the translation strategy recommended by Hannay \& Keizer (1993) for the pronominal adverbs so typical of the modern West Germanic verb-second languages (see (21) above). Ball's conclusion is that the functions of preposing have changed, and the acceptability of dislocation has declined since Chaucer's time. The dislocation we see in (26) is in fact Contrastive Left Dislocation (CLD), a different phenomenon from Hanging Topic Left Dislocation (HTLD), which is the more usual dislocation structure in PE. CLD crucially relies on deictic elements to link the dislocation to the clause. The Dutch examples in (27) illustrate the various possibilities. Note how the translations have to resort to HTLDs, inversions, and the $t h / w h$-clause. The deictic linking elements are given in italics. All examples are taken from de Vries (2007), but the bracketing of optional elements is mine: ${ }^{11}$

11 Note that deleting the deictics in italics is also optional in the sense that without them we have standard verbsecond clauses: Joop mag ik niet, etc. (see Koster 1981: 200ff, on whose examples the set in (27) is ultimately based). Koster (1981) and de Vries (2007) argue that CLD is in fact (verb-second) Topicalization; Koster takes 
(27) (a) (Die) Joop, die mag ik niet. (that) Joop DEM like I not 'Joop I don't like.'

(b) (Daar) in de tuin, daar zaten ze. (there) in the garden there sat they 'In the garden is where they sat.'

(c) (Toen) tijdens de vergadering, toen brak de hel los (Then) during the meeting then broke the hell loose 'It was during the meeting that all hell broke loose.'

(d) Dat hij zo laks is, dat ergert mij. that he so sloppy is that annoys me

'That he is so sloppy, that's what annoys me.'

De Vries (2007) demonstrates that CLD in Dutch shows reconstruction effects (unlike HTLD), which suggests that the dislocated constituent is moved to that dislocated position out of the clause rather than being generated there as in HTLD. This explains why CLD may target any category that can be targeted by (verb-second) Topicalization, which explains why there are no syntactic restrictions at all. HTLD in PE (and Dutch), on the other hand, is far more restricted and targets NPs only; it always involves resumptive pronouns. Note that a second deictic element is optionally present in CLD (as shown by the brackets), which suggests that CLD is in fact the 'correlative' construction that is a notable feature of $\mathrm{OE}$ syntax. Ball notes that $\mathrm{OE}$ often uses a correlative where PE uses a cleft (Ball 1991: 483); cf. the structure that we find in the OE translation of Boethius, in a passage very similar to the one in (28):

(28) Ac forbæmpe heora dysige men wafiað and hi him pincað deore, but for that that theygen foolish men crave and they themDAT seem precious forpam bu hi gaderast and helst on pinum horde. for that you theyACC gather and hold in your treasure 'But it is because foolish men crave them and think them precious that you collect them and keep them among your possessions.' $\quad<$ Bo 14.31.12>

CLD, then, always involves a deictic element in the verb-second topic position.

CLD is possible in PE; witness (29), from Birner \& Ward (2002: 1413):

(29) The people who earn millions and pay next to no tax, those are our targets.

They can apparently only be subjects, which is why the translations of nonsubject CLDs as in (25) and (26) have resort to the $t h / w h$-clause or that eModE innovation, the stressedfocus it-cleft. But even as subjects, marked topics are restricted; the independent use of demonstratives has become limited over the centuries to inanimate referents, especially in the singular. Plural those can refer to people, but the same is not true of singular that (see e.g. Huddleston \& Pullum 2002: 1504); witness the unacceptability of the literal 
translation of the Dutch sentence of (30):

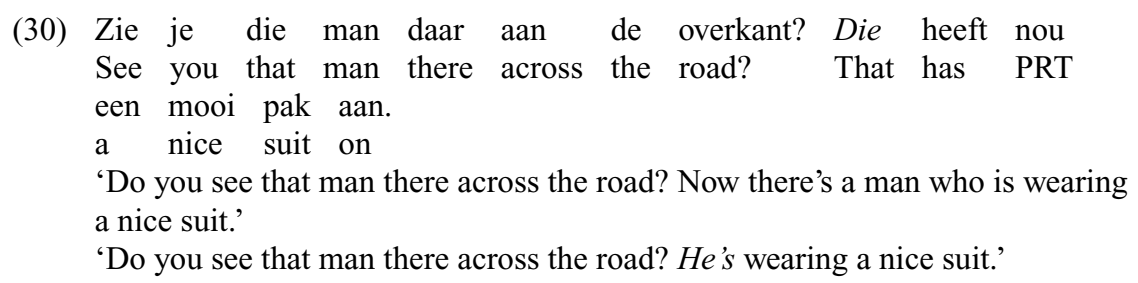

The discourse function of the demonstrative die 'that' in a sentence like (30) has been described as ' topic-shift' (Comrie 2000), indicating that this topic should be identified as the focus of the preceding sentence. The second translation of (30) shows that die can also be translated by a pronoun with contrastive stress, but not by a demonstrative. Example (31), from ca. 1000 (taken from Ball 1991: 52), shows se, the masculine nominative singular form of peet 'that', with a discourse function similar to die in (30):

(31) Aneas fuit filius Veneris; is est, qui vicit Turnum

Eneas wæs Veneres sunu; se oferswiðe Turnum.

Æneas was Venus' son DEM-m.n.s conquered Turnum

'Æneas was Venus' son; that one conquered Turnus.' <ÆGram 98.22>

Note that in (31), Ælfric translates the Latin cleft with a syntactically unmarked simple sentence; the demonstrative se 'that one' in the high preverbal position is marked enough. Ball notes that the deictic pat gives way to the pronoun hit in a number of functions in ME (Ball 1991:14); the loss of that for animate discourse referents might be related to the loss of grammatical gender on nouns. Nominal gender was lost in early Middle English; those may have been able to keep its function as independent demonstrative for human referents because the plural forms of the demonstrative were common to all genders. Even so, the se paradigm in Old English was far more versatile in its referring functions; examples like (32) abound:

(32) Be pam awrat Moyses se mæra heretoga, In principio fecit By those wrote Moses the great general, In principio fecit Deus celum et terram Deus celum et terram 'About those words Moyses the great general wrote: In principio fecit Deus celum et terram...' <ÆHom I, 70, 46>

(quoted in van Kemenade, forthcoming)

The translation shows that PE requires a more specific link to the preceding discourse.

CLD was rampant in OE (see van Kemenade (forthcoming) for more examples). Van Kemenade demonstrates that the loss of the se-paradigm, and the split into the definite article the and the demonstrative that, both invariant, meant the loss of a type of discourse reference that was both definite and specific; when used as 'definite determiners' in a NP, this not only made that NP definite but also gave it a specific reference to a discourse antecedent because of the morphological marking (for gender and number). 
The correlative or CLD construction in $\mathrm{OE}$ and ME is a versatile construction that allows specificational readings of constituents of all syntactic functions, phrases as well as clauses. As CLD is associated with verb-second topicalization, CLD came to be restricted to subjects only after the loss of verb-second. Discourse linking was further compromised by changes in the demonstrative system and the loss of gender, which is why CLD with a demonstrative in PE is only possible with plural referents. As the functions of the CLD construction are now expressed by it-clefts, the conclusion seems warranted that clefts emerged as a response to the impact of the loss of verb-second on the discourse and IS of English.

\subsection{The need for more subjects}

In verb-second, a single constituent from anywhere in the clause is placed before the finite verb. This constituent is very versatile with respect to its discourse functions: it may provide marked or unmarked links with the preceding discourse. After verbsecond is lost, these discourse functions of the first constituent appear to be allotted to different positions: presubject position, which is pragmatically marked, and subject position, which is pragmatically neutral. It follows that the subject in PE is the only way in which a sentence can link up to the preceding discourse without evoking any special discourse relations and assumptions. As the function of the subject is apparently reserved for unmarked themes, subjects become very important. We find this greater need for subjects reflected in the rise of quite unusual subject strategies in PE, as compared to Dutch and German; PE instances as in (33a) are not possible in Modern Dutch (witness (33c)).

(33) (a) 2004 saw the advent of routers with turbo modes.

(b) In 2004 kwamen de eerste routers met turbo modes op de markt.

(c) *2004 zag de komst van de eerste routers met turbo modes. (after www.cnet.com.au/wireless/routers/)

The sheer amount of material translated from English into Dutch and German means that instances like (33c) do occasionally appear in actual texts as the result of too literal translations. Manuals and other advice on translation contain explicit warnings against such practices:

(34) (a) Anti-aging therapies will undoubtedly have to counter many destructive biochemical processes at once. (Original English text)

(b) *Wirksame Therapien müssten allerdings den Kampf gegen viele zerstörerische biochemische prozess gleichzeitig aufnehmen (literal translation; House 2005: 97)

(c) Die therapien der Zukunft müssten allerdings gleichzeitig gegen viel zerstörerische Prozesse eingesetzt werden können (recommended translation; ibid. 98)

'Future therapies will undoubtedly have to be employed to counter many destructive biochemical processes at once.' (My translation of the recommended translation of (34c)) 
House points out that 'future therapies' are not agentive enough in German to 'counter' anything, and recommends a passive. Subjects are also prototypically agentive in PE, but the requirements of syntax and information structure apparently override such considerations, and the result is that $\mathrm{PE}$ is much less resistant to having nonagents as subjects of agentive actions.

The prototypical way to create subjects is passivization, and we do indeed find a greater reliance on passives for structuring information after ME (e.g. Halliday 2000). Not only do we see an increase in relative numbers, we also see the rise of passive constructions that were not possible before lME: not only prepositional passives of the type he was well thought of and passivized indirect objects like He was given a book (see also Allen 1995), but also specifically passive ECM-constructions. The first tentative instances of these new passives in ME predate the loss of the verb-second system (for ECM see e.g. Warner 1982) and do not appear to have an information-structural motivation; but frequencies take off after the fifteenth century, and their motivation in PE is overwhelmingly information-structural (Seoane 2006; Huddleston \& Pullum 2002).

ECM, or Exceptional Case-Marking, constructions as in He believed John to be lying, also known in the literature as 'Subject-to-Object Raising' and 'Accusativus-cumInfinitivo' constructions, first appear in Latin-inspired translations in the fourteenth century (e.g. Warner 1982) but take off in other registers in late Middle English. One of the peculiarities of the construction is the fact that, from its earliest emergence right up to the present day, it largely occurs in the passive (e.g. Fischer 1989 and the studies cited there for ME, and Fanego 1992 for Shakespearean English), so much so even that some fifty verbs of thinking and declaring only allow the construction in the passive (as in (35a)), not in the active (e.g. (35b)); see Postal (1974):

(35) (a) John was rumoured/said to be lying,

(b) *They rumoured/said John to be lying.

The only verbs that robustly allow the active construction are believe, consider, prove and expect. ${ }^{12}$ As actives are considered syntactically more basic than passives, which are generally analysed as being derived from actives by a syntactic operation, this phenomenon requires an explanation. A first hint of what might be going on was given by Mair (1990) in a corpus study of infinitives. Noting the predominance of passives in his corpus, he hypothesized that the subject of a passive ECM construction (here given in bold) serves as an unmarked way to connect its clause to the

12 Postal (1974) and others (e.g. Lasnik \& Saito 1993) have argued that the ECM construction after desiderative verbs such as want, which, unlike the verbs of thinking and declaring, only occurs in the active, not in the passive, is in fact a different construction, much more akin to the to-infinitival object-control construction seen in He persuaded me to see a doctor, a construction that has been around in English since the earliest recorded texts - i.e. they are directive, three-place verbs that may develop causative two-place variants (see Los 1999, 2005 for a discussion). Expect in some of its more directive uses, and possibly like (We'd like all parents to supervise their children at all times), should probably be classified with the want-verbs rather than with the verbs of thinking and declaring. 
previous one:

(36) Thanks to the ubiquitous television set, the best known Canadians in Britain are, quite possibly, Bernard Braden, Hughie Green and Robert McKenzie. Others more talented - Jon Vickers, Lynn Seymour, Mordecai Richler, Sir William Butlin, John Hemming, Oscar Petersen, Garfield Weston, Paul Anka, Glenn Ford, Yvonne de Carlo, Raymond Burr, Donald Sutherland and Christopher Plummer - are probably seldom identified as Canadians. Many of them are generally assumed to be Americans, which raises the whole struggle to maintain a separate identity from her giant neighbour. (Mair 1990: 180)

The predominance of passive ECM is in fact the result of the conflicting demands of textual coherence and the rigid word order of Present-day English. The alternatives to (36), listed in (37), will not do, because the link with the preceding text (many of them) is not in its canonical position as unmarked theme - its medial position gives it far greater prominence than is desirable (ibid.):

(37) (a) People generally assume many of them to be Americans.

(b) People generally assume that many of them are Americans.

(c) It is generally assumed that many of them are Americans.

In verb-second languages like Dutch and $\mathrm{OE}$, the constituent before the finite verb may constitute the unmarked theme, and as there are no syntactic or categorial restrictions on the first position it follows that Dutch or OE unmarked themes do not have to be subjects, but can be adverbials, or objects, as we saw in the previous section. Compare the Dutch translations of (36), provided in (38), which unproblematically start off with a nonsubject constituent van deze mensen 'of these people':

(38) (a) Van deze mensen neemt men meestal aan dat ze Amerikanen zijn of these people takes one generally on that they Americans are

(b) Van deze mensen wordt meestal aangenomen dat ze Amerikanen zijn. of these people is generally taken-on that they Americans are

Considering the construction in this light, i.e. as a solution to the conflicting demands of syntax and information structure created by the loss of verb-second, provides us with an explanation for the predominance of passives without having to resort to $\mathrm{ad}$ hoc syntactic constraints like Postal's Derived Object Constraint (Postal 1974: 305).

\section{Conclusion}

OE exhibits the operation of a verb-second rule much like Modern Dutch and German: a single constituent precedes the finite verb, without any restrictions on syntactic or discourse function. The decline of verb-second is a complex process difficult to chart: because subjects in the relevant structures (the 'inverted' surface order XP $-\mathrm{V}-$ $\mathrm{S}$ and the 'uninverted' surface order XP $-\mathrm{S}-\mathrm{V}$ ) may be situated in any of four different positions, depending on the type of subject (nominal versus pronominal), the type of XP constituent (whether a wh-word, negation, an adverb of the then-group 
or something else) and the type of verb (passive, unaccusative or something else). It is evident, however, that the old system has broken down by $1 \mathrm{ME}$. With the loss of verb-second, the discourse functions of the first constituent come to be divided up between presubject and subject position. The presubject position is pragmatically marked (prominent), the subject position is pragmatically unmarked. As correlative constructions and Contrastive Left Dislocation appear to have dwindled at the same period as verb-second was lost, and these constructions are associated with verbsecond in the literature, the decline of such structures, and their replacement by clefts, pseudoclefts and Hanging Topic Left Dislocations are likely to be phenomena related to the loss of verb-second, as are the higher numbers of passives, and the emergence of innovations like passive ECM and prepositional passives.

Although much research still remains to be done, it is clear that studying the changes in the structure of the left edge of the clause will tell us much about interaction between syntax and information structure, which, so far, seems to be bi-directional: syntactic change (the loss of verb-second) affects discourse, and pressure from discourse results in syntactic change (i.e. the emergence of new constructions). The fact that information structure can be compromised by changes in syntax lends support to the status of information structure as a separate linguistic level that should not be modelled as part of syntax.

Author's address:

Engelse Taal en Cultuur

Radboud Universiteit

Postbus 9103

6500 HD Nijmegen

The Netherlands

B.Los@let.ru.nl

\section{References}

Aboh, E. O. 2004. The morphosyntax of complement-head sequences: Clause structure and word order pattern in Kwa. New York: Oxford University Press.

Aboh, E. O. 2006. Complementation in Saramaccan and Gungbe: The case of c-type modal particles. Natural Language and Linguistic Theory 24, 1-55.

Allen, C. L. 1995. Case-marking and reanalysis: Grammatical relations from Old to Early Modern English. Oxford: Clarendon Press.

Auer, P. 1996. The pre-front field in spoken German and its relevance as a grammaticalization position. Pragmatics 6(3), 295-322.

Bækken, B. 1998. Word order patterns in Early Modern English, with special reference to the position of the subject and the finite verb. Oslo: Novus Press.

Ball, C. N. 1991. The historical development of the it-cleft. Ann Arbor: ProQuest/UMI Dissertation Services.

Ball, C. N. 1994. The origins of the informative-presupposition it-cleft. Journal of Pragmatics 22, 603-28.

Birner, B. \& G. Ward. 1998. Information status and canonical word order in English. Amsterdam and Philadelphia: Benjamins. 
Birner, B. \& G. Ward. 2002. Information packaging. In R. Huddleston \& G. K. Pullum (eds.), The Cambridge grammar of the English language, 1363-447. Cambridge: Cambridge University Press.

Bohnacker, U. \& C. Rosén. 2007. How to start a V2 declarative clause: Transfer of syntax vs. information structure in L2 German. In M. Anderssen \& M. Westergaard (eds.), Papers from the Language Acquisition Workshop SCL 2006, Nordlyd 34(3), 29-56.

Breivik, L. E. \& T. Swan. 1994. Initial adverbials and word order in English with special reference to the Early Modern English period. In D. Kastovsky (ed.), Studies in Early Modern English, 11-43. Berlin: Mouton de Gruyter.

Bybee, J. 2001. Main clauses are innovative, subordinate clauses are conservative: Consequences for the nature of constructions. In J. Bybee \& M. Noonan (eds.), Complex sentences in grammar and discourse: Essays in honor of Sandra A. Thompson, 1-17. Amsterdam and Philadelphia: Benjamins.

Comrie, B. 1989. Language universals and linguistic typology: Syntax and morphology. Oxford: Blackwell.

Comrie, B. 2000. Pragmatic binding: Demonstratives as anaphors in Dutch. In M. L. Juge \& J. L. Moxley (eds.), The twenty-third annual meeting of the Berkeley Linguistics Society, 50-61. Berkeley: Berkeley Linguistics Society.

Crawford, S. J. (ed.). 1922. The Old English version of the Heptateuch, AElfric's Treatise on the Old and New Testament and his Preface to Genesis. Early English Text Society Original Series 160. London: Milford, Oxford University Press.

Denison, D. 1985. Why Old English had no prepositional passive. English Studies 66, 189-204.

Denison, D. 1993. English historical syntax. London and New York: Longman.

Doherty, M. 2003. Topikalisierungsstrategien aus der Perspektive diskursadäquater Übersetzungen. Linguistische Berichte 194, 183-212.

Downing, A. \& P. Locke. 1995. A university course in English grammar. Hemel Hempstead: Phoenix ELT.

Ellegård, A. 1953. The auxiliary 'do': The establishment and regulation of its use in English. Stockholm: Almqvist \& Wiksell.

Engel, U. 1974. Syntaktische Besonderheiten der deutschen Alltagssprache. In G. Ungeheuer (ed.), Gesprochene Sprache, Jahrbuch 1972 (Sprache der Gegenwart 26), 199-228. Düsseldorf: Schwann.

Fabricius-Hansen, C. \& K. Solfjeld. 1994. Deutsche und norwegische Sachprosa im Vergleich: Ein Arbeitsbericht (Arbeitsberichte des Germanischen Instituts der Universität Oslo 6). Oslo.

Fanego, T. 1992. Infinitive complements in Shakespeare's English. Santiago de Compostela: Universidade de Santiago de Compostela (Servicio de Publicacións e Intercambio Científico).

Fischer, O. C. M. 1989. The origin and spread of the accusative and infinitive construction in English. Folia Linguistica Historica 8, 143-217.

Fischer, O., A. van Kemenade, W. Koopman \& W. van der Wurff. 2000. The syntax of early English. Cambridge: Cambridge University Press.

Haeberli, E. 2002. Observations on the loss of Verb Second in the history of English. In C. J.-W. Zwart \& W. Abraham (eds.), Studies in comparative Germanic syntax: Proceedings from the 15th workshop on Comparative Germanic Syntax, 245-72. Amsterdam and Philadelphia: Benjamins.

Haeseryn, W., K. Romijn, G. Geerts, J. de Rooij \& M. C. van den Toorn. 1997. Algemene Nederlandse spraakkunst, vols. 1 and 2. 2nd revised edition. Groningen: Martinus Nijhoff.

Halliday, M. A. K. 1994. An introduction to functional grammar. London: Edward Arnold. Halliday, M. A. K. 2000. Grammar and daily life. In David G. Lockwood, Peter H. Fries \& James E. Copeland (eds.), Functional approaches to language, culture and cognition: 
Papers in honor of Sydney M. Lamb, 221-37. Amsterdam and Philadelphia: John Benjamins.

Hannay, M. \& E. Keizer 1993. Translation and contrastive grammar: The grammatical versus the communicative strategy. Toegepaste Taalwetenschap in Artikelen 45, 65-88.

Healey, A. D. \& R. L. Venezky. 1985 [1980]. A microfiche concordance to Old English. Toronto: The Pontifical Institute of Mediaeval Studies.

Hock, H. H. 1986. Principles of historical linguistics. Berlin, New York and Amsterdam: Mouton de Gruyter.

House, J. 2005. Offene und verdeckte Übersetzung: Zwei Arten, in einer anderen Sprache 'das Gleiche' zu sagen. Zeitschrift für Literaturwissenschaft und Linguistik 35, 76-101.

Howell, R. B. 2006. Immigration and koineisation: The formation of early modern Dutch urban vernaculars. Transactions of the Philological Society 104, 207-28.

Huddleston, R. \& G. K. Pullum. 2002. The Cambridge grammar of the English language. Cambridge: Cambridge University Press.

Jacobsson, B. 1951. Inversion in English: With special reference to the Early Modern English period. Uppsala: Almqvist and Wiksell.

Jespersen, O. 1937. Analytic syntax. Copenhagen: Levin \& Munksgaard.

Kemenade, A. van. 1987. Syntactic case and morphological case in the history of English. Dordrecht: Foris.

Kemenade, A. van. 2000. Jespersen's cycle revisited: Formal properties of grammaticalization. In S. Pintzuk, G. Tsoulas \& A. Warner (eds.), Diachronic syntax: Models and mechanisms. Oxford: Oxford University Press. 51-74.

Kemenade, A. van. 2009. Discourse relations and word order change. In R. Hinterhölzl \& S. Petrova (eds.), New approaches to word order variation and change in the Germanic languages, 91-118. Berlin: Mouton.

Kemenade, A. van \& B. Los. 2006. Discourse adverbs and clausal syntax in Old and Middle English. In A. van Kemenade \& B. Los (eds.), The handbook of the history of English, 224-48. Oxford: Blackwell.

Koopman, W. 1995. Verb-final main clauses in Old English prose. Studia Neophilologica 67, 129-44.

Koster, J. 1975. Dutch as an SOV language. Linguistic Analysis 1, 111-36.

Koster, J. 1981. Locality principles in syntax. Dordrecht: Foris.

Kouwenberg, S. 1992. From OV to VO; Linguistic negotiation in the development of Berbice Dutch creole. Lingua 88, 263-99.

Kroch, A. S. 1989. Reflexes of grammar in patterns of language change. Language Variation and Change 1, 199-244.

Kroch, A., S. Pintzuk \& J. Myhill. 1982. Understanding DO. In K. Tuite, R. Schneider \& R. Chametzky (eds.), Papers from the 18th Regional Meeting of the Chicago Linguistic Society, 282-94. Chicago: Chicago Linguistic Society.

Kroch, A., A. Taylor \& D. Ringe 2000. The Middle English verb-second constraint: A case study in language contact and language change. In S. C. Herring, P. van Reenen \& L. Sch $\varnothing$ sler (eds.), Textual parameters in older languages, 353-91. Amsterdam and Philadelphia: Benjamins.

Lambrecht, K. 1994. Information structure and sentence form. Cambridge: Cambridge University Press.

Lasnik, H. \& M. Saito. 1993. On the subject of infinitives. In L. Dobrin, L. Nichols \& R. M. Rodriguez (eds.), Papers from the 27th Regional Meeting of the Chicago Linguistic Society, 324-43. Chicago: Chicago Linguistic Society.

Lemmens, M. \& T. Parr. 1995. Handboek voor de Vertaler Nederlands-Engels. Groningen: Wolters-Noordhoff. 
Lenker, U. 2007. Forwhi 'because': Shifting deictics in the history of English causal connection. In U. Lenker \& A. Meurman-Solin (eds.), Connectives in the history of English, 193-227. Amsterdam and Philadelphia: Benjamins.

Lightfoot, D. W. 1979. Principles of diachronic syntax. Cambridge: Cambridge University Press.

Lightfoot, D. W. 1999. The development of language. Oxford: Blackwell.

Los, B. 1999. Infinitival complementation in Old and Middle English. The Hague: Thesus.

Los, B. 2005. The rise of the to-infinitive. Oxford: Oxford University Press.

Mair, C. 1990. Infinitival complement clauses in English: A study of syntax in discourse. Cambridge: Cambridge University Press.

Mitchell, B. 1985. Old English syntax, 2 vols. Oxford: Clarendon Press.

Mitchell, B., C. Ball \& A. Cameron (eds.). 1975. Short titles of Old English texts. Anglo-Saxon England 4, 207-21.

Mitchell, B., C. Ball \& A. Cameron (eds.). 1979. Addenda and corrigenda. Anglo-Saxon England 8, 331-3.

Neeleman, A. \& H. van de Koot. 2007. The nature of discourse templates. MS, University College London.

Nevalainen, T. 1997. Recycling inversion: The case of initial adverbs and negators in Early Modern English. In J. Fisiak (ed.), A festschrift for Roger Lass on his sixtieth birthday (Studia Anglia Poznaniensia), 203-14. Poznań: Uniwersytet im Adama Mickiewicza w Poznaniu.

Noël, D. 1998. Infinitival copular complement clauses in English: Explaining the predominance of passive matrix verbs. Linguistics 36(6), 1045-63.

Noël, D. 2001. The passive matrices of English infinitival complement clauses. Studies in Language 25, 255-96.

Pérez-Guerra, J. 2005. Word order after the loss of the verb-second constraint or the importance of early Modern English in the fixation of syntactic and informative (un-) markedness. English Studies 86, 342-69.

Pintzuk, S. 1991. Phrase structures in competition: Variation and change in Old English word order. MS, University of Pennsylvania.

Pintzuk, S. \& A. S. Kroch. 1989. The rightward movement of complements and adjuncts in the Old English of Beowulf. Language Variation and Change 1, 115-43.

Pollock, J. Y. 1989. Verb movement, Universal Grammar, and the structure of IP. Linguistic Inquiry 20, 365-424.

Postal, P. M. 1974. On Raising: One rule of English grammar and its theoretical implications. Cambridge, MA: MIT Press.

Prince, E. F. 1978. A comparison of $w h$-clefts and it-clefts in discourse. Language 54, 883906.

Prince, E. F. 1981. Towards a typology of given-new information. In P. Cole (ed.), Radical pragmatics, 223-55. New York: Academic Press.

Prince, E. F. 1985. Fancy syntax and 'shared knowledge'. Journal of Pragmatics 9, 65-81.

Quirk, R., S. Greenbaum, G. Leech \& J. Svartvik. 1985. A grammar of contemporary English. Harlow: Longman.

Rizzi, L. 1997. The fine structure of the left periphery. In L. Haegeman (ed.), Elements of grammar: Handbook in generative syntax, 281-337. Dordrecht: Kluwer.

Roberts, I. 1993. A formal account of grammaticalization in the history of Romance futures. Folia Linguistica Historica 13, 219-58.

Roberts, I. \& A. Roussou. 2003. Syntactic change: A minimalist approach to grammaticalization. Cambridge: Cambridge University Press.

Schmidt, D. 1980. A history of inversion in English. MS, Ohio State University. 
Seoane, E. 2006. Information structure and word order change: The passive as an information-rearranging strategy in the history of English. In A. van Kemenade \& B. Los (eds.), The handbook of the history of English, 360-91. Oxford: Blackwell.

Smith, J. J. 1996. An historical study of English: Function, form and change. London \& New York: Routledge.

Smits, A. 2002. How writers begin their sentences: Complex beginnings in native and learner English (LOT Dissertations 67). Utrecht: LOT.

Speyer, A. 2005. A prosodic factor for the decline of topicalisation in English. In S. Kepser \& M. Reis (eds.), Linguistic evidence: Empirical, theoretical and computational perspectives (Studies in Generative Grammar 85), 485-506. Berlin and New York: Mouton de Gruyter.

Stutterheim, C. von \& M. Carroll. 2005. Subjektwahl und Topikkontinuität im Deutschen und Englischen. Zeitschrift für Literaturwissenschaft und Linguistik, 35, 7-27.

Thomason, S. G. 2001. Language contact: An introduction. Edinburgh: Edinburgh University Press.

Townend, M. 2002. Language and history in Viking Age England: Linguistic relations between speakers of Old Norse and Old English. Turnhout: Brepols.

Traugott, E. C. 1972. The history of English syntax: A transformational approach to the history of English sentence structure. New York: Holt, Rinehart and Winston.

Verner, K. 1875. Eine Ausnahme der ersten Lautverschiebung. Zeitschrift für vergleichende Sprachforschung 23, 97-130.

Virtanen, T. 1992. Discourse functions of adverbial placement in English: Clause-initial adverbials of time and place in narratives and procedural place descriptions. Åbo: Åbo Akademi University Press.

Vries, M. de. 2007. Dislocation and backgrounding. In B. Los \& M. v. Koppen (eds.), Linguistics in the Netherlands 2007, 236-48. Amsterdam and Philadelphia: John Benjamins.

Warner, A. 1982. Complementation in Middle English and the methodology of historical syntax. London: Croom Helm.

Warner, A. 2004. What drove $d o$ ? In C. J. Kay, S. Horobin \& J. J. Smith (eds.), New perspectives on English historical linguistics, 229-42. Amsterdam and Philadelphia: John Benjamins.

Warner, A. 2007. Parameters of variation between verb-subject and subject-verb order in late Middle English. English Language and Linguistics 11, 81-111.

Wurff, W. van der. 2001. Review of Bjørg Bækken 1998, Word order patterns in Early Modern English, with special reference to the position of the subject and the finite verb (Studia Anglistica Norvegica 9). Oslo: Novus Press. Studies in Language 25, 685-91. 